\title{
The Chemical Reactivity Study of Organotin(IV) 4-aminobenzoates Using Cyclic Voltammetry and Antioxidant Activity Test by the DPPH Method
}

\author{
WIDIA SARI, HARDOKO INSAN QUDUS*, SUTOPO HADI
}

Department of Chemistry, Universitas Lampung, Bandar Lampung, Indonesia 35145

\begin{abstract}
Chemical reactivity studies of the organotin(IV) carboxylates diphenyltin(IV) di-4-aminobenzoate (1) and triphenyltin(IV) 4-aminobenzoate (2) were conducted using cyclic voltammetry. Then, their antioxidant activities were tested by the 2,2-diphenyl-1-picrylshydrazyl (DPPH) method. Cyclic voltammetry was used to determine the kinetic constants of compounds $\mathbf{1}$ and $\mathbf{2}$ for the forward chemical reaction $\left(k_{f}\right)$. The constant values of the chemical reaction rate of 1 and $\mathbf{2}$ on cyclic voltammogram by experiment were obtained by comparing with the values from digital simulation methods obtained using Polar software 5.8.3. The results demonstrated that the constant value of the rate of the subsequent chemical reaction is a function of the rate of its potential (slope $=\mathrm{kf} / \mathrm{v}$ ); that is, 6.481 and $6.069 \mathrm{l} / \mathrm{V}$ for 1 and 2, respectively. The type of chemical reaction mechanism that occurs around the surface of the working electrode follows reaction mechanism of electrochemical reaction is quasi reversible and chemical reaction is irreversible $\left(E_{q} C_{i}\right)$. The antioxidant activities of compounds 1 and 2 produced $I C_{50}$ values of 5.91 and $12.57 \mu \mathrm{g} / \mathrm{mL}$, respectively. These results indicate that both compounds are active as antioxidants. However, their antioxidant activities were lower than that of ascorbic acid, which has an $I_{50}$ value of $0.66 \mu \mathrm{g} / \mathrm{mL}$.
\end{abstract}

Keywords: antioxidant, forward chemical rate constant $\left(k_{f}\right)$; organotin(IV) 4-aminobenzoate; Polar 5.8.3; cyclic voltammetry

\section{Introduction}

Organotins are compounds that have at least one Sn-C covalent bond. Organotin (IV) complexes have remarkable biological activities, whose strengths are determined by the number of organic groups that are bound to the central Sn atom [1]. Several biological activities can be stimulated by incorporating the ligands bound to Sn atoms to the organotin(IV) compounds. These ligands act as secondary determinants for the reactivity of organotin(IV) compounds [2]. Organotin(IV) compounds have a plethora of applications because of their antifungal [3-5], antitumor [6-10], corrosion inhibitor [11-14], antimalarial [15-18], and antibacterial properties [19, 20]. The ability to bind or reduce free radicals [2123] makes them a great antioxidant. as in organotin(II) compounds with flavonoid compounds [24, 25] and organotin(IV) compounds with carboxylic acid derivatives [23]. Compared to other organotin(IV) compounds, organotin(IV) carboxylate compounds have received special attention for their wide applications and appreciable biological properties.

The chemical reactivity of a compound is determined by calculating the constant value of the rate of an advanced chemical reaction $\left(\mathrm{k}_{\mathrm{f}}\right)$. Cyclic voltammetry is an analytical method for calculating the magnitude of a chemical reaction's rate constant [26]. Examining chemical kinetics of cyclic voltammetric reactions provides information about the chemical reactivity of an alkylating agent, which helps assess the usefulness or toxicity of an organotin [27, 28]. The electrochemical simulation and data analysis software, Polar 5.8.3 software is usually used to determine kf [27-29].

Organotin(IV) carboxylate is recognized for its usefulness and wide range of interesting applications.

*email: hardoko.insan@fmipa.unila.ac.id 
In this study, we aimed to determine the chemical reactivity of the organotin(IV) carboxylate compounds diphenyltin(IV) di-4-aminobenzoate and triphenyltin(IV) 4-aminobenzoate by using cyclic volta-mmetry. We also examined the antioxidant properties of these compounds using the 2,2-diphenyl1-picrylhydrazyl (DPPH) method using a similar procedure applied by others [30-32].

\section{Materials and methods}

\subsection{Materials}

All reagents used were of analytical reagent grade. High-grade water, methanol, DPPH, ascorbic acid, $\mathrm{NaCl}$, and dimethylsulfoxide (DMSO) were purchased from Sigma-Aldrich and were used as is. Diphenyltin(IV) di-4-aminobenzoate $\left(\mathrm{C}_{6} \mathrm{H}_{5}\right)_{2} \mathrm{Sn}\left(\mathrm{OCOC}_{6} \mathrm{H}_{4} \mathrm{NH}_{2}\right)_{2}$ (1) and triphenyltin(IV) 4-aminobenzoate $\left(\mathrm{C}_{6} \mathrm{H}_{5}\right)_{3} \mathrm{Sn}\left(\mathrm{OCOC}_{6} \mathrm{H}_{4} \mathrm{NH}_{2}\right)(2)$ were already available in our laboratory.

\subsection{Instrumentation}

The optical densities were measured using a UV-Shimadzu UV-245 spectrophotometer. The ER644 integrated potentiostat eDAQ system was used for cyclic voltammetry. The potentiostat is a threeelectrode system, in which the gold wire acts as the working electrode, silver wire as the reference electrode, and platinum wire as the counter electrode. Cyclic voltammetry was conducted under the following conditions:

(1) Initial potential $\left(E_{\text {initial }}\right):+700 \mathrm{mV}$;

(2) End potential ( $\left.E_{\text {end }}\right):+1400 \mathrm{mV}$;

(3) Temperature: $25^{\circ} \mathrm{C}$;

(4) Working electrode: gold $(\mathrm{Au})$;

(5) Auxiliary electrode: platinum $(\mathrm{Pt})$;

(6) Reference electrode: silver $(\mathrm{Ag}) / \mathrm{AgCl}$;

(7) Potential scanning rate (v): varied every100 mV/s (from 100 to $700 \mathrm{mV} / \mathrm{s}$ ).

\subsection{Preparation of Standard Solutions 1 and 2}

Two milliliters of $1 \mathrm{mM}$ standard solutions 1 and 2 was added to $0.5 \mathrm{~mL}$ of $0.1 \mathrm{M} \mathrm{NaCl}$. After mixing, the concentrations of the standard solutions and the $\mathrm{NaCl}$ were modified to $0.8 \mathrm{mM}$ and $0.02 \mathrm{M}$, respectively.

\subsection{Characterization of Reactions Mechanisms $\left(E_{x} C_{x}\right)$}

The characteristic of an electrochemical reaction can be known from the constant value of the standard heterogen electron transfer, whereas the characteristic of a chemical reaction can be known by forward chemical reaction constant $\left(\mathrm{k}_{\mathrm{f}}\right)$ and reverse chemical reaction constant $\left(\mathrm{k}_{\mathrm{b}}\right)$ [33]. The reaction mechanism that occurs on the surface of a working electrode is $\mathrm{E}_{\mathrm{x}} \mathrm{C}_{\mathrm{x}}$. Electrochemical reaction mechanisms $\left(E_{x}\right)$ on the surface of an electrode are reversible (r), quasi reversible (q), and irreversible (i). In this study, the characterization of $x$ in an electrochemical reaction $\left(E_{x}\right)$ was determined by calculating ks using the Polar 5.8.3 software under the following conditions [34]:

(1) $\mathrm{r}$ (reversible), if $\mathrm{k}_{\mathrm{s}}>0.3 v^{1 / 2} \mathrm{~cm} / \mathrm{s}$;

(2) $\mathrm{q}$ (quasi-reversible), if $\mathrm{k}_{\mathrm{s}}>2.5 \times 10^{-5} v^{1 / 2} \mathrm{~cm} / \mathrm{s}$;

(3) $\mathrm{i}$ (irreversible), if $\mathrm{k}_{\mathrm{s}}<2.5 \times 10^{-5} v^{1 / 2} \mathrm{~cm} / \mathrm{s}$;

The values of potential scanning rate $\left(v^{1 / 2}\right)$ were obtained from the experiment.

\subsection{Antioxidant Activity Test}

Antioxidant activity test by DPPH method was performed according to a previous method used by others [21-23, 30-32]. Briefly, the compounds to be tested were dissolved in methanol at concentrations of $2 ; 4 ; 8 ; 16$, and $32 \mu \mathrm{M}$. To each test solution, DPPH $(0.1 \mathrm{mM}$ in methanol) was added and mixed thoroughly. The solution was left aside for $30 \mathrm{~min}$. The absorbance of the mixture at a wavelength of $517 \mathrm{~nm}$ was measured using a UV-vis spectrophotometer. Antioxidant activity was calculated as the 
percentage of inhibition against DPPH. Percentage inhibition or percentage of DPPH radical capture activity was calculated using Equation 1:

$$
\text { Percentage inhibition }=\left\{\frac{\text { Control absorbance }- \text { Sample absorbance }}{\text { Control absorbance }}\right\} \times 100 \% \text {. }
$$

The $\mathrm{IC}_{50}$ of each sample concentration was calculated using the linear regression equation. The sample concentration was plotted in the $\mathrm{x}$ axis and percentage of inhibition in the $\mathrm{y}$ axis. From the equation $\mathrm{y}-\mathrm{a}+\mathrm{bx}$, the value of $\mathrm{IC}_{50}$ was calculated using Equation 2.

$$
\mathrm{IC}_{50}=\frac{50-\mathrm{a}}{\mathrm{b}}
$$

where $y$ is the percentage inhibition (50), a is the intercept (intersection of lines the y axis), b is the slope, and $\mathrm{x}$ is the concentration.

\section{Results and discussions}

The results of the cyclic voltammetry of tested compounds are presented in Figures 1 and 2, and that of the blank solution is presented in Figure 3. The peak current $\left(i_{p}\right)$ and peak potential $\left(E_{p}\right)$ data obtained from the voltammogram of compounds $\mathbf{1}$ and $\mathbf{2}$ are presented in Table 1.

Table 1. Voltammogram of compounds 1 and 2

\begin{tabular}{|c|c|c|c|c|}
\hline $\begin{array}{c}\text { Potential } \\
\text { Scanning } \\
\text { Rate } \\
(\mathrm{V} / \mathrm{s})\end{array}$ & $\begin{array}{c}\mathrm{E}_{\mathrm{p}} \text { Experiment } \\
\text { diphenyltin(IV) di-4- } \\
\text { amino-benzoate (Volt) }\end{array}$ & $\begin{array}{c}\mathrm{i}_{\mathrm{p}} \text { Experiment } \\
\text { diphenyltin(IV) di-4- } \\
\text { amino-benzoate }(\mu \mathrm{A})\end{array}$ & $\begin{array}{c}\mathrm{E}_{\mathrm{p}} \text { Experiment } \\
\text { triphenyltin(IV) 4- } \\
\text { aminobenzoate (Volt) }\end{array}$ & $\begin{array}{c}\mathrm{i}_{\mathrm{p}} \text { Experiment } \\
\text { triphenyltin(IV) 4- } \\
\text { aminobenzoate }(\mu \mathrm{A})\end{array}$ \\
\hline 0.1 & 1.05 & 46.123 & 1.06 & 42.098 \\
\hline 0.2 & 1.065 & 52.713 & 1.085 & 49.682 \\
\hline 0.3 & 1.070 & 56.336 & 1.11 & 52.825 \\
\hline 0.4 & 1.085 & 60.148 & 1.12 & 56.408 \\
\hline 0.5 & 1.095 & 63.292 & 1.13 & 59.157 \\
\hline 0.6 & 1.105 & 65.755 & 1.14 & 61.831 \\
\hline 0.7 & 1.115 & 68.497 & 1.15 & 64.36 \\
\hline
\end{tabular}

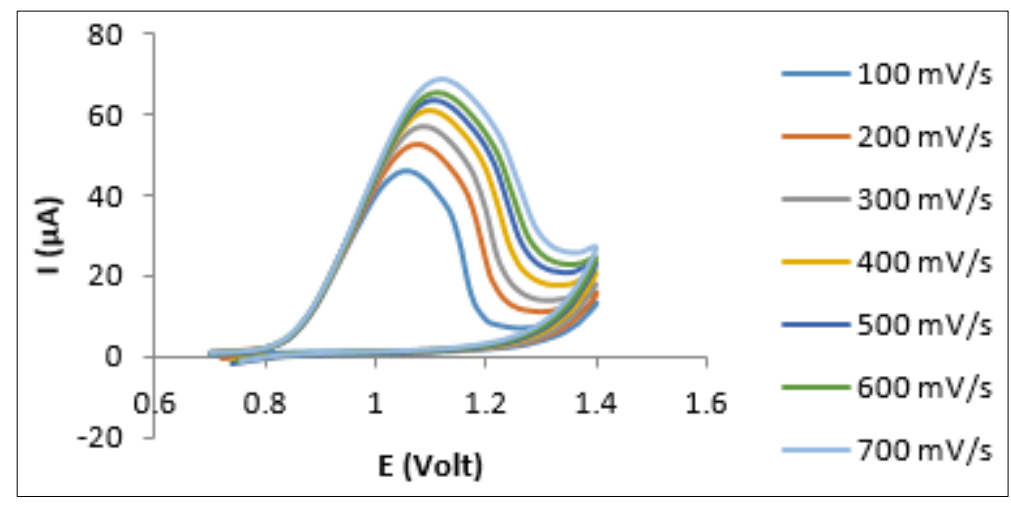

Figure 1. The voltammogram of blank $100 \mathrm{mV} / \mathrm{s}$ and compound $10.8 \mathrm{mM}$ by varying the potential scanning rate with cyclic voltammetry 


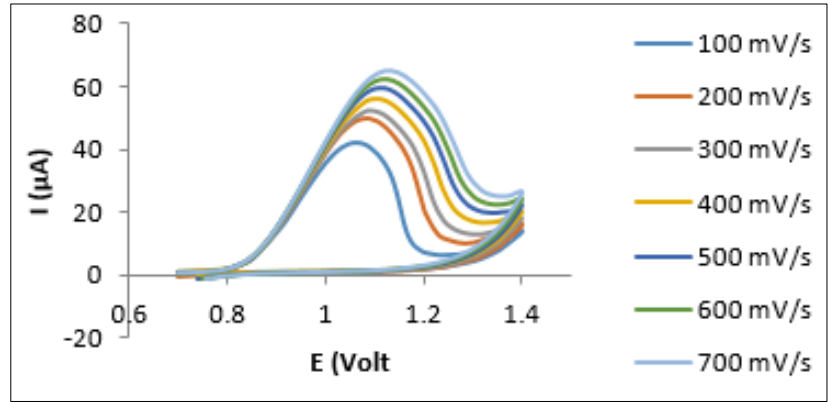

Figure 2. The voltammogram of blank $100 \mathrm{mV} / \mathrm{s}$ and compound 2

$0.8 \mathrm{mM}$ by varying the potential scanning rate with cyclic voltammetry

The increase of oxidation peak current $\left(i_{p}\right)$ in the measurement of standard solutions $\mathbf{1}$ and $\mathbf{2}$ were influenced by the potential scanning rate (Table 1). The higher the velocity of the potential scanning speed, the higher is the current generated. In this study, blank measurements were taken to ensure the peak potential values of the blanks that appeared differed from the peak potential values of the measured standard solutions. In fact, the blank solution did not demonstrate an oxidation or reduction peak in each variation of the potential scanning rate (Figure 3).

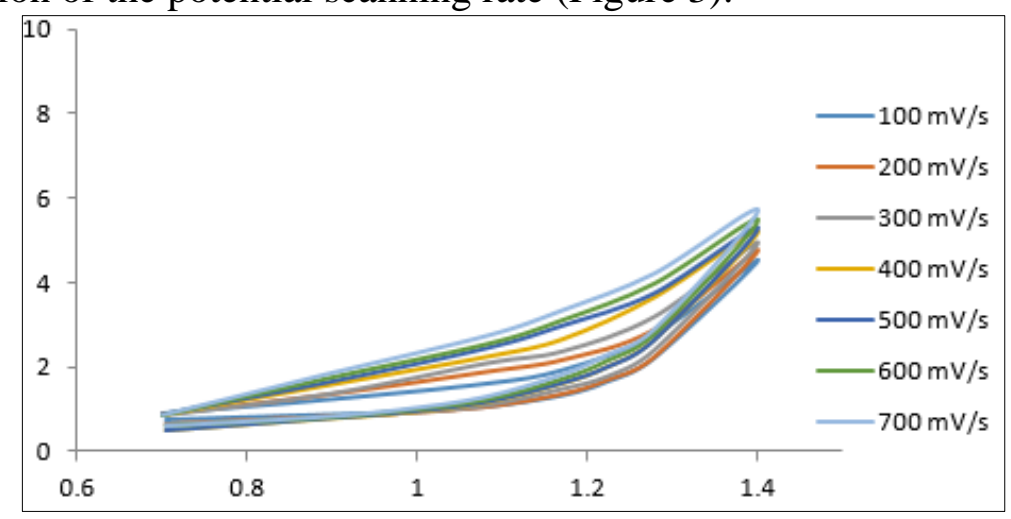

Figure 3. The cyclic voltammogram of blank solution

Table 2. The Values of $\mathrm{K}_{\mathrm{s}}, \mathrm{A}, \mathrm{E}^{\circ}$, and $\mathrm{k}_{\mathrm{f}}$ simulation result (cyclic voltammogram) of compound 1 using Polar 5.8.3 Software

\begin{tabular}{|c|c|c|c|c|c|c|c|c|}
\hline $\mathrm{V}$ & A & $\mathrm{k}_{\mathrm{s}}$ & $\mathrm{T}$ & \multirow{2}{*}{$\alpha$} & $\mathrm{E}^{\circ}$ & $\mathrm{kf}_{\mathrm{f}}$ & $\mathrm{D} \times 10^{-4}$ & $\mathrm{C}$ \\
\hline$(\mathrm{mV} / \mathrm{s})$ & $\left(\mathrm{cm}^{2}\right)$ & $(\mathrm{cm} / \mathrm{s})$ & $\left({ }^{\circ} \mathrm{C}\right)$ & & (volt) & $(1 / s)$ & $\left(\mathrm{cm}^{2} / \mathrm{s}\right)$ & $(\mathrm{mM})$ \\
\hline 0.1 & 0.00785 & 0.007 & 25 & 0.4 & 0.8187 & 0.5916 & 0.645 & 0.008 \\
\hline 0.2 & 0.00785 & 0.007 & 25 & 0.4 & 0.8194 & 1.2546 & 0.645 & 0.008 \\
\hline 0.3 & 0.00785 & 0.007 & 25 & 0.4 & 0.8203 & 1.9481 & 0.645 & 0.008 \\
\hline 0.4 & 0.00785 & 0.007 & 25 & 0.4 & 0.8254 & 2.6060 & 0.645 & 0.008 \\
\hline 0.5 & 0.00785 & 0.007 & 25 & 0.4 & 0.8310 & 3.2516 & 0.645 & 0.008 \\
\hline 0.6 & 0.00785 & 0.007 & 25 & 0.4 & 0.8398 & 3.8605 & 0.645 & 0.008 \\
\hline 0.7 & 0.00785 & 0.007 & 25 & 0.4 & 0.8455 & 4.4695 & 0.645 & 0.008 \\
\hline
\end{tabular}

Table 3. The values of $\mathrm{k}_{\mathrm{s}}, \mathrm{A}, \mathrm{E}^{\circ}$, and $\mathrm{k}_{\mathrm{f}}$ simulation result (cyclic voltammogram) of compound 2 using Polar 5.8.3 Software

\begin{tabular}{|c|c|c|c|c|c|c|c|c|}
\hline $\mathrm{V}$ & A & $\mathrm{ks}_{\mathrm{s}}$ & $\mathrm{T}$ & \multirow{2}{*}{$\alpha$} & $\mathrm{E}^{\circ}$ & $\mathrm{kf}_{\mathrm{f}}$ & $\mathrm{D} \times 10^{-4}$ & $\mathrm{C}$ \\
\hline$(\mathrm{mV} / \mathrm{s})$ & $\left(\mathrm{cm}^{2}\right)$ & $(\mathrm{cm} / \mathrm{s})$ & $\left({ }^{\circ} \mathrm{C}\right)$ & & (volt) & $(1 / \mathrm{s})$ & $\left(\mathrm{cm}^{2} / \mathrm{s}\right)$ & $(\mathrm{mM})$ \\
\hline 0.1 & 0.00785 & 0.007 & 25 & 0.4 & 0.8286 & 0.6017 & 0.645 & 0.008 \\
\hline 0.2 & 0.00785 & 0.007 & 25 & 0.4 & 0.8421 & 1.2121 & 0.645 & 0.008 \\
\hline 0.3 & 0.00785 & 0.007 & 25 & 0.4 & 0.8582 & 1.8154 & 0.645 & 0.008 \\
\hline 0.4 & 0.00785 & 0.007 & 25 & 0.4 & 0.8612 & 2.4980 & 0.645 & 0.008 \\
\hline 0.5 & 0.00785 & 0.007 & 25 & 0.4 & 0.8682 & 3.0494 & 0.645 & 0.008 \\
\hline 0.6 & 0.00785 & 0.007 & 25 & 0.4 & 0.8721 & 3.6616 & 0.645 & 0.008 \\
\hline 0.7 & 0.00785 & 0.007 & 25 & 0.4 & 0.8802 & 4.2222 & 0.645 & 0.008 \\
\hline
\end{tabular}


The cyclic voltammogram parameter values obtained from the experimental results were used as reference values for simulations using the Polar 5.3.8 software. The parameters that affected the shape of the simulated cyclic voltammogram were $\mathrm{k}_{\mathrm{s}}$ (standard heterogeneous electron transfer rate constants), $\mathrm{D}$ (diffusion coefficient), $\mathrm{E}^{\circ}$ (standard cell potential), $v$ (potential scanning rate), $\alpha$ (electron transfer coefficient), and $\mathrm{k}_{\mathrm{f}}$ (rate constant of an advanced chemical reaction). This simulation was performed by varying the parameters in the Polar software 5.8.3, thus it will affect the height of the peak current and the potential peak produced.

The values of $\mathrm{k}_{\mathrm{s}}, \alpha, \mathrm{E}^{\circ}$, and $\mathrm{k}_{\mathrm{f}}$ on the kinetic menu are presented in Tables 2 and 3 . The matching of parameter values of anodic peak current and anodic peak potential on the voltammogram of the experiment data and simulation are presented in Tables 4 and 5, respectively.

Table 4. The Matching result pf $E_{p}$ and $i_{p}$ experimental values with $E_{p}$ and $i_{p}$ simulation result from Polar 5.8.3 Software of compound 1

\begin{tabular}{|c|c|c|c|c|}
\hline $\begin{array}{c}\text { Potential } \\
\text { Scanning Rate } \\
(\mathrm{V} / \mathrm{s})\end{array}$ & $\begin{array}{c}\text { Ep Experiment } \\
(\text { Volt })\end{array}$ & $\begin{array}{c}\text { Ep Simulation } \\
(\text { Volt })\end{array}$ & $\mathrm{i}_{\mathrm{p} \text { Experiment }(\mu \mathrm{A})}$ & $\mathrm{i}_{\mathrm{p}}$ Simulation $(\mu \mathrm{A})$ \\
\hline 0.1 & 1.05 & 1.05 & 46.123 & 46.123 \\
\hline 0.2 & 1.065 & 1.065 & 52.713 & 52.713 \\
\hline 0.3 & 1.07 & 1.07 & 56.336 & 56.336 \\
\hline 0.4 & 1.085 & 1.085 & 60.148 & 60.148 \\
\hline 0.5 & 1.095 & 1.095 & 63.292 & 63.292 \\
\hline 0.6 & 1.105 & 1.105 & 65.755 & 65.755 \\
\hline 0.7 & 1.115 & 1.115 & 68.497 & 68.497 \\
\hline
\end{tabular}

Table 5. The Matching result pf $E_{p}$ and $i_{p}$ experimental values with $E_{p}$ and $i_{p}$ simulation result from Polar 5.8.3 Software of compound 2

\begin{tabular}{|c|c|c|c|c|}
\hline $\begin{array}{c}\text { Potential } \\
\text { Scanning Rate } \\
(\mathrm{V} / \mathrm{s})\end{array}$ & E $_{\mathrm{p}}$ Experiment (Volt) & E $_{\mathrm{p}}$ Simulation (Volt) & i $\mathrm{i}_{\mathrm{p}}$ Experiment $(\mu \mathrm{A})$ & $\mathrm{i}_{\mathrm{p}}$ Simulation $(\mu \mathrm{A})$ \\
\hline 0.1 & 1.06 & 1.06 & 42.098 & 42.098 \\
\hline 0.2 & 1.085 & 1.085 & 49.682 & 49.682 \\
\hline 0.3 & 1.11 & 1.11 & 52.825 & 52.825 \\
\hline 0.4 & 1.12 & 1.12 & 56.408 & 56.408 \\
\hline 0.5 & 1.13 & 1.13 & 59.157 & 59.157 \\
\hline 0.6 & 1.14 & 1.14 & 61.831 & 61.831 \\
\hline 0.7 & 1.15 & 1.15 & 64.360 & 64.360 \\
\hline
\end{tabular}

Based on the data in Tables 2 and 3, the $\mathrm{k}_{\mathrm{f}}$ value is applied to the value of the potential scanning rate $(v)$, thus the linear regression curve produces a correlation value (r) above 99\% (Figures 4 and 5). This states that the linearity relationship between $\mathrm{k}_{\mathrm{f}}$ and $v$ is very good.

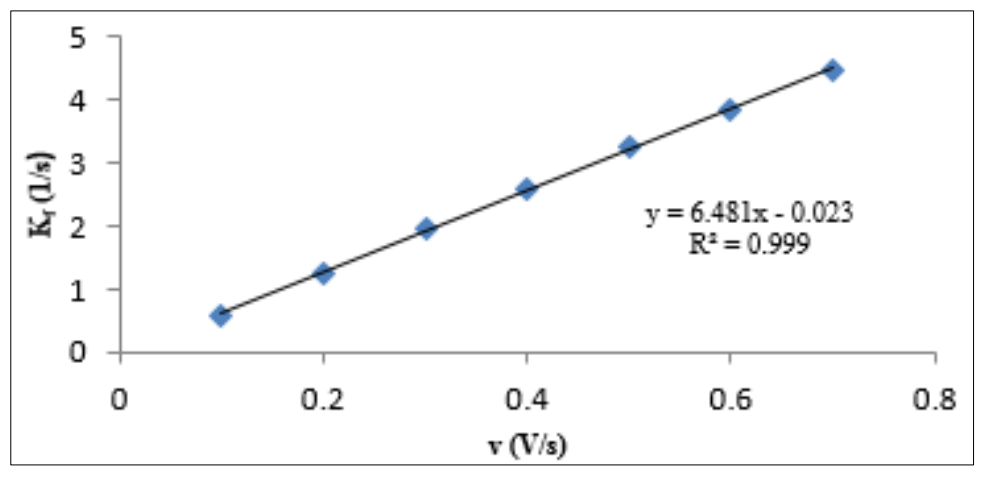

Figure 4. Linear regression curve of $\mathrm{k}_{\mathrm{f}}$ against potential scanning rate $(v)$ of compound 1 


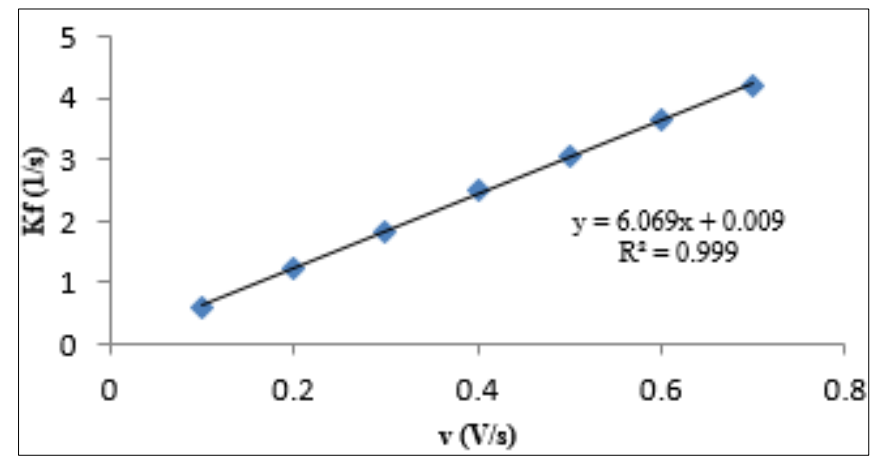

Figure 5. Linear regression curve of $\mathrm{k}_{\mathrm{f}}$ against potential scanning rate $(v)$ of compound $\mathbf{2}$

Table 6. The calculation of $\mathrm{k}_{\mathrm{s}}$ value with Polar 5.8.3 Software

\begin{tabular}{|c|c|c|c|c|}
\hline $\begin{array}{c}\text { Potential Scanning Rate } \\
(\mathrm{V} / \mathrm{s})\end{array}$ & $\mathrm{k}_{\mathrm{s}}$ Polar & $0.3 \mathrm{v}^{1 / 2}$ & $2.5 \times 10^{-5} \mathrm{v}^{1 / 2}$ & $\mathrm{E}_{\mathrm{x}}$ \\
\hline 0.1 & 0.007 & 0.0949 & $7.90 \times 10^{-5}$ & $\mathrm{q}$ \\
\hline 0.2 & 0.007 & 0.1342 & $1.11 \times 10^{-5}$ & $\mathrm{q}$ \\
\hline 0.3 & 0.007 & 0.1643 & $1.37 \times 10^{-5}$ & $\mathrm{q}$ \\
\hline 0.4 & 0.007 & 0.1897 & $1.58 \times 10^{-5}$ & $\mathrm{q}$ \\
\hline 0.5 & 0.007 & 0.2121 & $1.77 \times 10^{-5}$ & $\mathrm{q}$ \\
\hline 0.6 & 0.007 & 0.2324 & $1.93 \times 10^{-5}$ & $\mathrm{q}$ \\
\hline 0.7 & 0.007 & 0.2510 & $2.09 \times 10^{-5}$ & $\mathrm{q}$ \\
\hline
\end{tabular}

On the basis of $\mathrm{k}_{\mathrm{s}}$ values presented in Table 6 , it is clear that all $\mathrm{k}_{\mathrm{s}}$ values are $>2.5 \times 10^{-5} v^{1 / 2} \mathrm{~cm} / \mathrm{s}$, thus the electrochemical reaction of compounds $\mathbf{1}$ and $\mathbf{2}$ follows a quasi-reversible electrochemical reaction $\left(\mathrm{E}_{\mathrm{q}}\right)$, implying that the process of electron transfer from electrons to the electrode surface occurs more slowly than the reversible state $\left(E_{r}\right)$ [29]. The cyclic voltammograms produced by compounds 1 and $\mathbf{2}$ did not demonstrate a cathodic current peak $\left(\mathrm{i}_{\mathrm{pc}}\right)$, because there has been a subsequent chemical reaction one-way irreversible $\left(\mathrm{C}_{\mathrm{i}}\right)$ so that the value of $\mathrm{k}_{\mathrm{b}}$ in the submenu input at Polar 5.8.3 software is filled with zero [27, 28].

Antioxidant activity was measured by analyzing the reduction in absorbance level data from DPPH after adding the compounds at specified concentrations. The results of this absorbance will show the effect of compound tested on DPPH, where the antioxidant activity is in line with the decrease in absorbance of DPPH. The absorbance values for concentrations of 2, 4, 8, 16, and $32 \mu \mathrm{M}$ were obtained for all the test samples (Tables 7-9). The $\mathrm{IC}_{50}$ value was calculated using the linear regression equation $y=a x+b$ (Figure 6). IC 50 value is the effective concentration required for a compound to reduce 50\% of the total DPPH. Therefore, when y was substituted by 50 , the $\mathrm{IC}_{50}$ values for diphenyltin(IV) 4aminobenzoate and triphenyltin(IV) 4-aminobenzoate were $11.79 \mu \mathrm{M}(5.91 \mu \mathrm{g} / \mathrm{mL})$ and $25.88 \mu \mathrm{M}$ $(12.57 \mu \mathrm{g} / \mathrm{mL})$, respectively. The $\mathrm{IC}_{50}$ value for ascorbic acid was $3.75 \mu \mathrm{M}(0.66 \mu \mathrm{g} / \mathrm{mL})$.

The absorbances and percentage inhibitions of compound $\mathbf{1}$, compound $\mathbf{2}$, and ascorbic acid against DPPH are presented in Tables 7-9, respectively.

Table 7. Data of absorbance measurement for compound 1 against DPPH

\begin{tabular}{|c|c|c|c|c|}
\hline $\begin{array}{c}\text { Concentration } \\
(\mu \mathrm{M})\end{array}$ & $\begin{array}{c}\text { Sample } \\
\text { absorbance }\end{array}$ & $\begin{array}{c}\text { Control } \\
\text { absorbance }\end{array}$ & \%Inhibition & $\begin{array}{l}\mathrm{IC}_{50} \\
(\mu \mathrm{M}) \\
\end{array}$ \\
\hline 2 & 0.524 & \multirow{5}{*}{0.9917} & 47.1614 & \multirow{5}{*}{11.79} \\
\hline 4 & 0.513 & & 48.2706 & \\
\hline 8 & 0.501 & & 49.4807 & \\
\hline 16 & 0.481 & & 51.4974 & \\
\hline 32 & 0.453 & & 54.3209 & \\
\hline
\end{tabular}


Table 8. Data of absorbance measurement for compound $\mathbf{2}$ against DPPH

\begin{tabular}{|c|c|c|c|c|}
\hline $\begin{array}{c}\text { Concentration } \\
(\mu \mathrm{M})\end{array}$ & $\begin{array}{c}\text { Sample } \\
\text { absorbance }\end{array}$ & $\begin{array}{c}\text { Control } \\
\text { absorbance }\end{array}$ & \%Inhibition & $\begin{array}{l}\mathrm{IC}_{50} \\
(\mu \mathrm{M})\end{array}$ \\
\hline 2 & 0.550 & \multirow{5}{*}{0.9917} & 44.5397 & \multirow{5}{*}{25.88} \\
\hline 4 & 0.539 & & 45.6489 & \\
\hline 8 & 0.532 & & 46.3547 & \\
\hline 16 & 0.512 & & 48.3715 & \\
\hline 32 & 0.485 & & 51.0941 & \\
\hline
\end{tabular}

Table 9. Data of absorbance measurement for ascorbic acid against DPPH

\begin{tabular}{|c|c|c|c|c|}
\hline $\begin{array}{c}\text { Concentration } \\
(\mu \mathrm{M})\end{array}$ & $\begin{array}{c}\text { Sample } \\
\text { absorbance }\end{array}$ & $\begin{array}{c}\text { Control } \\
\text { absorbance }\end{array}$ & \%Inhibition & $\begin{array}{l}\mathrm{IC}_{50} \\
(\mu \mathrm{M}) \\
\end{array}$ \\
\hline 2 & 0.523 & \multirow{5}{*}{0.9915} & 47.2516 & \multirow{5}{*}{3.75} \\
\hline 4 & 0.501 & & 49.4705 & \\
\hline 8 & 0.429 & & 56.7322 & \\
\hline 16 & 0.288 & & 70.9531 & \\
\hline 32 & 0.060 & & 93.9485 & \\
\hline
\end{tabular}
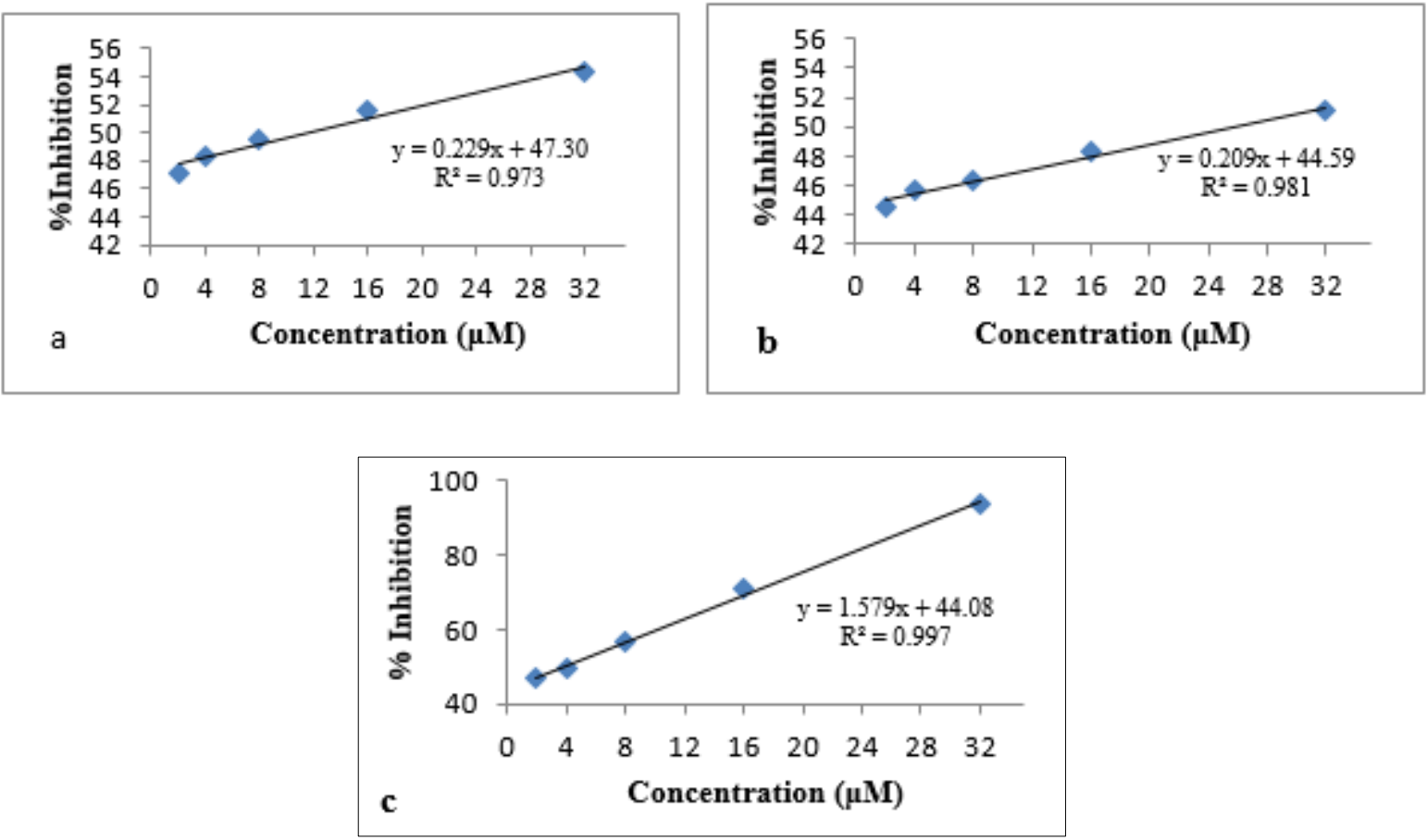

Figure 6. Linear regression curve of antioxidant (a) diphenyltin(IV) di-4-aminobenzoate; (b) triphenyltin(IV) 4-aminobenzoate; (c) ascorbic acid

Table 10. The strength level of antioxidant [35]

\begin{tabular}{|c|c|}
\hline IC $_{50}$ value $(\mu \mathrm{g} / \mathrm{mL})$ & Antioxidant intensity \\
\hline$<10$ & Very strong \\
\hline $10-50$ & Strong \\
\hline$>50-100$ & Medium \\
\hline$>100-250$ & Weak \\
\hline$>250$ & Inactive \\
\hline
\end{tabular}


Based on the reference values in Table 10, the antioxidant activities of compounds $\mathbf{1}$ and $\mathbf{2}$ were categorized into the strong (active) group. Carboxylic acid ligands bound to the $\mathrm{Sn}$ atom play a central role in increasing the biological activities of organotin(IV) compounds [1]. Compound 1 was stronger than compound 2 due to increased number of bound 4-aminobenzoic acid. Because aminobenzoic acid groups are electron donors, it is easier for them to donate electrons to stabilize the DPPH radicals when compared to compound $\mathbf{2}$, which has only a single aminobenzoate group attached. However, the antioxidant activities of these compounds were lower than that of ascorbic acid, which was classified into the highly strong group.

\section{Conclusions}

The results revealed that the values of the rate constant of the subsequent chemical reaction, which is a function of the potential scanning rate (slope $=\mathrm{k}_{\mathrm{f}} / v$ ), were 6.481 and $6.0691 / \mathrm{V}$ for compounds 1 and 2. The reaction occurring in these two compounds appeared to follow the EqCi reaction mechanism, in which the electrochemical reactions are quasi reversible and chemical reactions are irreversible. These two organotin(IV) compounds demonstrated remarkable antioxidant properties.

Acknowledgments: The authors would like to thank Enago (www.enago.com) for the English language proofread and review. We deeply thank to Institute of Research and Community Services, Universitas Lampung and Directorate of Research and Community Services, The Deputy of Research and Development, The Ministry of Research, Technology/National Research and Innovation Agency, Indonesia. that provided fund for this project to be undertaken through Penelitian Dasar (Basic Research Grant Scheme) 2020 with contract number of 179/SP2H/ADM/LT/DRPM/2020.

\section{References}

1. PELLERITO, L., NAGY, L., Organotin(IV $)^{\mathrm{n}+}$ complexes formed with biologically active ligands: equilibrium and structural studies, and some biological aspects, Coord. Chem. Rev., 224, 2002, 111 150.

2. SZORCSIK, A., NAGY, L., GADJA-SCHRANTZ, K., PELLERITO, L., NAGY, E., EDELMANN, E.T., Structural studies on organotin(IV) complexes formed with ligands containing $\{\mathrm{S}, \mathrm{N}, \mathrm{O}\}$ donor atoms, J. Radioanal. Nucl. Chem., 252(3), 2002, 523 - 530.

3. BONIRE, J.J., AYOKO, G.A., OLURINOLA, P.F., EHINMIDU, J.O., JALIL, N.S.N., OMACHI, A.A., Syntheses and Antifungal Activity of some organotin(IV)carboxylates, Metal-Based Drugs, 5(4), 1998, 233 - 236.

4. HADI, S., IRAWAN, B., EFRI, The Antifungal Activity Test of Some Organotin(IV) Carboxylates. J. Appl. Sci. Res., 4(11), 2008, 1521-1525.

5. HADI, S., RILYANTI, M., NURHASANAH, Comparative Study on the Antifungal Activity of Some Di- and Tributyltin(IV) Carboxylate Compounds, Modern Appl. Sci., 3(2), 2009, 12-17.

6. GIELEN, M., An Overview of Forty Years Organotin Chemistry Developed at the Free Universities of Brussels ULB and VUB, J. Braz. Chem. Soc., 14(6), 2003, 870-877.

7.LI, Y., LI, Y., NIU, Y., JIE, L., SHANG, X., GUO, J., LI, Q., Synthesis and antitumor activity of a new mixed-ligand complex di-n-butyl-(4-chlorobenzohydroxamato)tin(IV) chloride, J. Bioinorg. Chem., 102, 2008, 1731-1735.

8.REHMAN, W., BADSHAH, A., KHAN, S., TUYET, L.T.A., Synthesis, characterization, antimicrobial and antitumor screening of some diorganotin(IV) complexes of 2-[(9H-Purin-6-ylimino)]phenol. Eur. J. Med. Chem., 44(10), 2009, 3981-3985.

9. HADI, S., RILYANTI, M., Synthesis and in vitro anticancer activity of some organotin(IV) benzoate compounds, Orient. J. Chem., 26(3), 2010, 775-779.

10. HADI, S., RILYANTI, M., SUHARSO, In Vitro Activity and Comparative Studies of Some Organotin(IV) Benzoate Derivatives Against Leukemia Cancer Cell: L-1210, Indo. J. Chem., 12(1), 2012, 172-177. 
11. SINGH, R., CHAUDARY, P., KHAUSIK, N.K., A Review: Organotin Compounds in Corrosion Inhibition. Rev. Inorg. Chem., 30(4), 2010, 275-294.

12. HADI, S., AFRIYANI, H., ANGGRAINI, W.D., QUDUS, H.I., SUHARTATI, T., The Synthesis and Potency Study of Some Dibutyltin(IV) Dinitrobenzoate Compounds as Corrosion Inhibitor for Mild Steel HRP in DMSO-HCl Solution, Asian J. Chem., 27(4), 2015, 1509-1512

13. KURNIASIH, H., NURISSALAM, M., ISWANTORO, B., AFRIYANI, H., QUDUS, H.I., HADI, S., The Synthesis, Characterization and Comparative Anticorrosion Study of Some Organotin(IV) 4Chlorobenzoates, Orient. J. Chem., 31(4), 2015, 2377-2383.

14. HAZANI, N.N., MOHD, Y., GHAZALI, S.A.I.S.M., FARINA, Y., DZULKIFLI, N.N., Electrochemical Studies on Corrosion Inhibition Behaviour of Synthesised 2-acetylpyridine 4-ethyl-3thiosemicarbazone and Its Tin(IV) Complex for Mild Steel in $1 \mathrm{M} \mathrm{HCl} \mathrm{Solution,} \mathrm{J.} \mathrm{Electrochem.} \mathrm{Sci.}$ Technol., 10(1), 2019, 29-36.

15. HANSCH, C., VERMA, R.P., Larvicidal activities of some organotin compounds on mosquito larvae: A QSAR study, Eur J Med Chem., 44(1), 2009, 260-273.

16.HADI, S., NOVIANY, RILYANTI, M., In Vitro Antimalarial Activity of Some Organotin(IV) 2Nitrobenzoate Compounds Against Plasmodium falciparum, Macedon. J. Chem. Chem. Eng., 37(2), 2018, 185-191.

17. HADI, S., NOVIANY, QUDUS, H.I., WATTANA-AMORN, P., The Potency Study of Organotin (IV) 3-Nitrobenzoate Compounds as Antimalarial Agents. J Phys: Conf. Ser., 1338, 2019, 012012.

18. HADI, S., FENSKA, M.D., WIJAYA, R.A., NOVIANY, SUHARTATI, S., Antimalarial Activity of Some Organotin(IV) Chlorobenzoate Compounds against Plasmodium falciparum, Mediterr. J. Chem., 10(3), 2020 213-219.

19. ANNISSA, SUHARTATI, T., YANDRI, HADI, S., Antibacterial Activity of Diphenyltin(IV) and Triphenyltin(IV) 3-Chlorobenzoate againts Pseudomonas aeruginosa and Bacillus subtilis, Orient. J. Chem., 33(3), 2017, 1133-1139.

20. HADI, S., HERMAWATI, E., NOVIANY, SUHARTATI, T., YANDRI, Antibacterial Activity Test of DiphenyltinIV) Dibenzoate and Triphenyltin(IV) Benzoate Compounds against Bacillus substilis and Pseudomonas aeruginosa, Asian J. Microbiol. Biotech. Env. Sci., 20(1), 2018, 113-119.

21. SHPAKOVSKY, D.B., BANTI, C.N., MUKHATOVA, E.M., GRACHEVA, Y.A., OSIPOVA, V.P., BERBEROVA, N.T., ALBOV, D.V., ANTONENKO, T.A., ASLANOV, L.A., MILAEVA, E.R. AND HADJIKAKOU, S.K., Synthesis, Antiradical Activity and in vitro Cytotoxicity of Novel Organotin Complexes based on 2,6-di-tert-butyl-4-mercaptophenol, Dalton Transactions, 43, 2014, 6880-6890,.

22. TYURIN, V.Y., YAOUHAN, W., PRISHCHENKO, A.A., SHPAKOVSKY, D.B., GRACHEVA, Y.A., ANTONENKO, T.A., TAFEENKO, V.A., AL'BOV, D.V., ASLANOV, L.A. AND MILAEVA, E.R., Complexes of Organotin Compounds with bis- and Trisphosphonate Derivatives of 2,6-ditertbutylphenol Having Antioxidant Activity, Russ. Chem. Bull., 64(6), 2015, 1419-142.

23. JAVED, F., SIRAJUDDIN, M., ALI, S., KHALID, N., TAHIR, M.N., SHAH, N.A., RASHEED, Z., KHAN, M.R., Organotin (IV) Derivatives of $o$-Isobutyl Carbonodithioate : Synthesis, Spectroscopic Characterization, X-Ray Structure , HOMO / LUMO and in Vitro Biological Activities, Polyhedron, 104, 2016, 80-90.

24.DEHGHAN, G., KHOSHKAM, Z.,Tin(II)-Quercetin Complex : Synthesis, Spectral Characterisation and Antioxidant Activity, Food Chem., 131(2), 2012, 422-426.

25. PANHWAR, Q.K., MEMON, S., Synthesis , Characterization and Antioxidant Study of Tin(II)Rutin Complex : Exploration of Tin Packaging Hazards, Inorg. Chim. Acta, 407, 2013, 252-260.

26. YOSHIDA, K., Electrooxidation in Organic Chemistry, Reprint Edition, Florid: Krieger Publishing Company, 1993, pp. 16-72. 73-98. 219-246.

27.QUDUS, H.I., YUNITA, R.D., HADI, S., The Chemical Analysis of Triphenyltin(IV)phydroxybenzoate by by Square Wave Voltammetry, Orient. J. Chem., 33(5), 2017, 2518-2523. 
28. QUDUS, H.I., YUNITA, R.D., HADI, S., The Chemical Analysis of Two Triphenyltin(IV) Hydroxybenzoate Derivatives for Medicinal Purposes by Square Wave Voltammetry. Asian J. Chem., 32(7), 2020, (in press).

29. HUANG, W., Polar 5.8.3 for Windows: Electrochemical Simulation and DataAnalysis. W.S Ping Company, Sydney, 2014.

30. TRIFUNSCHI, S., MELANIA FLORINA MUNTEANU, M.F., Synthesis, Characterization and Antioxidant Activity of Cooper-Quercetin Complex and Iron-Quercetin Complex, Rev. Chim., 69(10), 2018, 2621-2624.

31. DELEANU, M., POPA, E.E., POPA, M.E., Chemical Composition and Active Properties Evaluation of Wild Oregano (Origanum Vulgare) and Ginger (Zingiber Officinale-Roscoe) Essential Oils, Rev. Chim., 69(8), 2018, 1927-1933.

32. FILDAN, A.P., PET, I., STOIN, D., BUJANCA. G., LUKINICH-GRUIA, A.T., JIANU, C., JIANU, A.M., RADULESCU, M., TOFOLEAN, D.E., Artemisia dracunculus Essential Oil: Chemical composition and antioxidant properties, Rev. Chim., 70(12), 2019, 59-62.

33. GOSSER, D.K., Cyclic Voltammetry Simulation and Analysis of Reaction Mechanism. New York: Wiley-VCH Inc, 1993, pp. 1-154.

34. BRETT, C.M.A., BRETT, A.M.O., Electrochemistry Principles, Methods, and Applications, New York: Oxford University Press, 1994, pp.174-197.

35. PHONGPAICHIT, S., NIKOM, J., RUNGJINDAMAI, N., SAKAYAROJ, J., TOWATANA, N.H., RUKACHAISIRIKUL, V., KIRTIKARA, K., Biological Activities of Extracts from Endophytic Fungi Isolated from Garcinia Plant. FEMS Immunol. Med. Microbiol., 51(3), 2007, 517-525.

$\overline{\text { Manuscript received: } 1.07 .2020}$ 